\title{
Factors Affecting Tax Collection in Pakistan: An Empirical Investigation
}

\author{
Azka Amin 1,*, Abdul Majeed Nadeem², Sadia Parveen ${ }^{3}$, Muhammad Asif Kamran ${ }^{4}$, Sofia Anwar ${ }^{1}$ \\ ${ }^{1}$ Department of Economics, GC University Faisalabad, Pakistan \\ ${ }^{2} \mathrm{PhD}$ Scholar Center of Economic Research, Shandong University, China \\ ${ }^{3}$ Lahore College for Woman University (LCWU) Lahore, Pakistan \\ ${ }^{4}$ Nuclear Institutes for Agriculture \& Biology (NIAB) Jhang Road Faisalabad, Pakistan \\ Corresponding author: amnsial@yahoo.com
}

Received May 06, 2014; Revised May 26, 2014; Accepted June 06, 2014

\begin{abstract}
Tax is a financial charge imposed on individuals by state in different forms like direct tax paid directly by individuals, indirect tax collected by intermediaries and deposited to Government like sales tax. Taxation plays an important role in the process of revenue generation and to run various activities in an economy. The study empirically demonstrates various factors involved in direct and indirect tax collection in Pakistan. Tax to GDP ratio, corruption, political instability, trade openness, real per capita income and inflation were considered main factors affecting tax collection in empirical testing. Corruption and political instability were measured by using corruption index and political instability index respectively. Time series data from 1980-2010 was used for regression analysis. Data of all variables was obtained from International Country Risk Guide (ICRG), Handbook of Statistics and Polity to Project IMF. Augmented Dickey Fuller (ADF) test was applied to check the stationarity of all variables. Autoregressive Distributed Lagged (ARDL) model was applied to find out long run and short run dynamics of models. The results indicated tax collection shrinks due to increasing corruption, inflation and political instability while trade openness and real per capita income boost tax revenues. The study suggested important policy implication for increasing tax collection in Pakistan.
\end{abstract}

Keywords: corruption, political instability, direct tax, indirect tax, ARDL co-integration

Cite This Article: Azka Amin, Abdul Majeed Nadeem, Sadia Parveen, Muhammad Asif Kamran, and Sofia Anwar, "Factors Affecting Tax Collection in Pakistan: An Empirical Investigation." Journal of Finance and Economics, vol. 2, no. 5 (2014): 149-155. doi: 10.12691/jfe-2-5-3.

\section{Introduction}

Developing countries face lower tax collection as compared to target amount due to inefficiencies in tax collection system [1]. In present study various factors are identified that affect tax collection in Pakistan. Due to some major problems like political backwardness, poor economic development, undefined taxation policies and inappropriate institutional capacity, Pakistan is still not successful to implement an efficient taxation system. Tax administration system of Pakistan is usually in hand of corrupt officers, as during last ten years all selected governments in Pakistan were indulge in corruption either it is petty (small scale) or grand (large scale) corruption [2]. Corruption is an illegal activity committed by people to gain personal benefit. It weakens the basic roots on which the progress of any country depends. Like a horrible disease, it prevails in private as well as in government institutions which ultimately destroys all parts of the economy $[3,4]$. In Pakistan the roots of corruption date back to the period when British government rewarded lands and titles to those people who were their loyalist. This was the starting of nepotism and corruption in the country [5]. Pakistan's corruption index was 2 in 2010, showing more than $70 \%$ corruption exists in Pakistan [6]. Tax collection is badly affected by corruption $[7,8]$. Due to corruption in taxation system, there is 50 percent revenue which remains uncollected [9-13]. In Pakistan, several factors like complications in tax structure and fixed corrupt contracts between tax payer and tax administrator boost corruption [14].

Political instability in Pakistan is one of the main reasons for lower tax revenues [15]. During the period of political instability, neither political authorities think for its public nor do they have any concern about the development of their country, so ultimately country faces the problem of lower tax collection. Increasing tax revenue can be achieved if proper steps taken towards political stability which is possible if total amount of tax revenue should be diverted away from corrupt government accounts [2,16,17].

Removal of trade restrictions, increasing per capita income and decreasing inflation are also main factors that boost tax revenue. Trade openness eliminates quantitative restrictions from goods and services which ultimately raise tax revenue. An open economy raises its tax revenue because the economy with large international trade considered as established and well organized [18]. Per 
capita income in rupee term has increased from Rs.118085 to Rs. 131543 during 2012-13 [19]. A strong positive relation exists between per capita income and tax collection. Increase in tax revenue is greatly responsive to change in inflation [20,21]. Indirect imposition of taxes on commodities creates inflation in the economy which is responsible for the reduction in purchasing power of the people and also tax collection. Inflation puts inverse impact on direct as well as on indirect taxes in Pakistan [22,23].

Previous literature on tax collection has looked at different variables impacting tax collection separately and has not put much emphasis on collective affect of tax determinants on tax collection. The objective of the current research is to find out various factors that affect tax collection in Pakistan and to check the stability of defined models are the main objectives of the study. This reminder of the paper is divided into sections namely, Introduction and background of the study is given, Methodology or Results and discussions and conclusion including policy recommendations and future research guidelines

\section{Material and Methods}

Time series data for period of 1980-2010 was obtained from Hand book of Statistics, International Country Risk Guide (ICRG) and Polity to Project of IMF. Tax revenue was measured in term of tax to GDP (Gross Domestic Product) ratio (Direct plus indirect taxes divided by Real GDP). Corruption and Political instability were measured by using corruption and political instability index respectively. Per capita income was estimated in term of real per capita income. Trade openness was measured as ratio of exports plus imports to GDP. Consumer Price Index (CPI) was used as a proxy of Inflation.

The standard form of direct tax to GDP ratio is given as:

$$
\begin{aligned}
& \text { LOGDTX } / \mathrm{GDP}=\delta_{0}+\delta_{1} \mathrm{CI}+\delta_{2} \mathrm{PI} \\
& +\delta_{3} \text { LOGTO }+\delta_{4} \text { LOGRPCI }+\delta_{5} \log \mathrm{CPI}+\mu_{\mathrm{t}}
\end{aligned}
$$

The standard form of indirect Tax to GDP ratio is given as:

$$
\begin{aligned}
& \text { LOGITX } / \text { GDP }=\delta_{0}+\delta_{1} \mathrm{CI}+\delta_{2} \mathrm{PI}+\delta_{3} \mathrm{LOGTO} \\
& +\delta_{4} \mathrm{LOGRPCI}+\delta_{5} \log \mathrm{CPI}+\mu_{\mathrm{t}}
\end{aligned}
$$

The standard form of total tax (direct plus indirect) to GDP ratio is given as:

$$
\begin{aligned}
& \mathrm{TAX} / \mathrm{GDP}=\delta_{0}+\delta_{1} \mathrm{CI}+\delta_{2} \mathrm{PI}+\delta_{3} \mathrm{TO} \\
& +\delta_{4} \mathrm{RPCI}+\delta_{5} \log \mathrm{CPI}+\mu_{\mathrm{t}}
\end{aligned}
$$

Equation (1) is used to find out effect of corruption, political instability, trade openness, real per capita income and inflation on direct taxes in Pakistan. The second equation describes how corruption, political instability, trade openness, real per capita income and inflation affect indirect taxes in Pakistan. Equation (3) shows the combine effect of various factors on tax revenue (direct plus indirect taxes).
Table 1. Description of Variables

\begin{tabular}{|c|c|c|}
\hline Variable Name & Description & $\begin{array}{c}\text { Unit of } \\
\text { Measurement }\end{array}$ \\
\hline Tax/GDP & $\begin{array}{c}\text { Tax (direct plus indirect) to } \\
\text { GDP ratio }\end{array}$ & Million Rupees \\
\hline DTX/GDP & Direct tax to GDP ratio & Million Rupees \\
\hline ITX/GDP & Indirect tax to GDP ratio & Million Rupees \\
\hline CI & Corruption index & Index \\
\hline PI & Political instability index & Index \\
\hline TO & Trade Openness & Million Rupees \\
\hline CPI & Consumer price index & Index \\
\hline RPCI & Real per capita income & Million Rupees \\
\hline
\end{tabular}

\section{Results and Discussion}

This section comprised three models of tax revenue. Model (1) and (2) explain how corruption, political instability, real per capita income, trade openness and inflation affected direct and indirect taxes in Pakistan respectively, while model (3) defines the combine impact of these factors on tax revenue.

Many scholars have studied affect of various factors on tax collection in Pakistan [4,6,17,18,20,24,25]. Current study was devised by identifying major issues raised in existing literature and selected variables to study the effect of these variables on direct tax collection, indirect taxes, and combined indirect and direct taxation. The basic idea behind separate analysis was to propose different policy options with respect to different taxation systems for better policy making to improve tax collection.

\subsection{Model 1: Direct Tax to GDP Ratio}

$$
\begin{aligned}
& \Delta L O G D T X / G_{t i}=\alpha+\sum_{i=1}^{k} \beta_{i} C I_{t-i}+\sum_{i=1}^{k} \chi_{i} P I_{t-i}+ \\
& \sum_{i=1}^{k} \delta_{i} L_{\text {OOGCPI }}+\sum_{t-i}^{k} \phi_{i} L_{i=1} \text { OGRPCI } I_{t-i}+\sum_{i=1}^{k} \lambda_{i} \text { LOGTO }_{t-i}+ \\
& \sum_{i=1}^{k} \eta_{i} L O G D T X / G D P_{t-i}+\sum_{i=1}^{k} v_{i} \Delta C I_{t-i}+\sum_{i=1}^{k} \varpi_{i} \Delta P I_{t-i}+ \\
& \sum_{i=1}^{k} \theta_{i} \Delta L O G C P I_{t-i}+\sum_{i=1}^{k} \sigma_{i} \Delta L O G R P C I_{t-i}+\sum_{i=1}^{k} \omega_{i} \Delta L O G T O_{t-i}+ \\
& \sum_{i=1}^{k} \zeta_{i} \Delta D T X / G D P_{t-i}
\end{aligned}
$$

Model (1) describes the effect of various factors such as corruption, political instability, real per capita income, trade openness and inflation on direct tax to GDP ratio in Pakistan. Before further regression analysis, first of all stationarity of all variables was checked. The purpose of stationarity was to test trend among variables because non- stationary time series usually cause spurious regression results, autocorrelation and high $\mathrm{R}^{2}$ that is not supported by economic theory.

Stationarity of data in time series analysis is very important as non-stationary variables provide spurious results i.e High $\mathrm{R}^{2}$ and Auto-correlation. In present study, Augmented Dickey Fuller (ADF) test was used to check stationary of variables, the results in table (2) illustrate the mixture of $\mathrm{I}(0)$ stationary at level and I(1) stationary at first difference, thus, Autoregressive Distributed Lagged (ARDL) approach is an appropriate technique. Corruption index (CI), political instability index (PI), log of real per capita income (log RPCI) and log of trade openness (log 
TO) were integrated at first order i-e I(1). While log of consumer price index (log CPI) and log of direct tax to GDP (log DTX/GDP) were integrated at level or at zero order i-e I(0). Probability revealed that these variables were significant at $1 \%$ and $5 \%$ level of significance.

Table 2. Testing Stationarity of Variables using Augmented Dickey Fuller (ADF) Test

\begin{tabular}{|c|c|c|c|c|c|c|}
\hline \multirow{2}{*}{ Variables } & \multicolumn{2}{|c|}{ At level } & \multicolumn{3}{c|}{ At $1^{\text {st }}$ difference } \\
\cline { 2 - 7 } & Test Stat & Prob & Results & Test Stat & Prob & Results \\
\hline Log DTX/GDP & $-5.39^{* * * *}$ & 0.00 & Stationary & -3.14 & 0.11 & Non Stationary \\
\hline CI & $-5.59^{* * *}$ & 0.00 & Stationary & $-4.10^{* *}$ & 0.01 & Stationary \\
\hline PI & -1.53 & 0.79 & Non Stationary & $-5.04^{* * *}$ & 0.00 & Stationary \\
\hline Log TO & -2.79 & 0.20 & Non Stationary & $-6.61^{* * *}$ & 0.00 & Stationary \\
\hline Log RPCI & -1.96 & 0.59 & Non Stationary & $-5.72^{* * *}$ & 0.00 & Stationary \\
\hline Log CPI & $-5.59^{* * * *}$ & 0.00 & Stationary & -2.79 & 0.20 & Non Stationary \\
\hline
\end{tabular}

**, ** shows $1 \%$ and $5 \%$ level of significance

ARDL bound test was first developed by [26] and it was applied to find out the long run relationship between variables. This approach provides better results when integration order is different and sample size is small. Two critical bounds that is lower bound I (0) and upper bound I (1) were presented by [26]. In case of calculated F-statistic was less than the lower bound, it shows non-existence of

long run relationship between variables and acceptance of null hypothesis. In case of F-value is greater than the upper bound then it shows existence of long run relationship and acceptance of alternative hypothesis. But if F-statistics lies between two critical bounds than results would be inconclusive.

Table 3. Bound Test Results

\begin{tabular}{|c|c|c|c|c|c|c|c|}
\hline \multirow{2}{*}{ F value } & \multirow{2}{*}{ Probability } & \multicolumn{2}{|c|}{ Critical value at 1\% } & \multicolumn{2}{|c|}{ Critical value at 5\% } & \multicolumn{2}{c|}{ Critical value at 10\% } \\
\cline { 2 - 8 } & & $\mathrm{I}(0)$ & $\mathrm{I}(1)$ & $\mathrm{I}(0)$ & $\mathrm{I}(1)$ & $\mathrm{I}(0)$ & $\mathrm{I}(1)$ \\
\hline $7.53^{* * *}$ & 0.00 & 6.34 & 7.52 & 4.87 & 5.85 & 4.19 & 5.06 \\
\hline
\end{tabular}

Autoregressive Distributed Lagged (ARDL) technique was then applied to find out existence of long run relationship among variables. The key assumption of ARDL is that all variables should be co integrated to I(0) and I(1). This would require the imposition of bound test. First lag order was selected through Schwarz-Bayesian criteria (SBC). Then calculated value of F-statistics was checked against critical value of Pesaran table of unrestricted intercept and trend [26]. This showed that null hypothesis i.e Non- existence of co -integration was rejected at $1 \%$ level so results indicate the existence of long run relationship among variables.

Table 4. Long run and short run dynamics of Direct Tax to GDP Ratio

\begin{tabular}{|c|c|c|c|c|c|}
\hline \multirow{2}{*}{ Variables } & \multicolumn{2}{|c|}{ Long Run Dynamics } & \multirow{2}{*}{ Variables } & \multicolumn{2}{|c|}{ Short Run Dynamics } \\
\hline & Coefficient & $\mathrm{t}$ - value & & Coefficient & t- value \\
\hline LOGCPI & $-0.63 * * *$ & -3.67 & $\Delta$ LOGCPI & -0.27 & -0.94 \\
\hline LOGTO & -0.15 & -0.31 & $\Delta$ LOGTO & -0.13 & -0.19 \\
\hline LOGRPCI & 0.40 & 1.08 & $\triangle$ LOGRPCI & 0.11 & 1.00 \\
\hline PI & $-0.98 * * *$ & -2.66 & $\Delta \mathrm{PI}$ & $0.29 * * *$ & 4.19 \\
\hline $\mathrm{CI}$ & $0.67 * *$ & 2.04 & $\Delta \mathrm{CI}$ & $0.18^{*}$ & 1.75 \\
\hline \multirow[t]{6}{*}{ CONSTANT } & 0.36 & 0.43 & $\triangle \mathrm{CONSTANT}$ & 0.10 & 0.42 \\
\hline & & & ECM & $-0.27 * * *$ & -4.99 \\
\hline & & & $\mathrm{R}^{2}$ & .97 & \\
\hline & & & Adjusted $\mathrm{R}^{2}$ & .95 & \\
\hline & & & F Stat & 55.89 & \\
\hline & & & DW & 2.40 & \\
\hline
\end{tabular}

(

The results showed that consumer price index (CPI) measured in the form of inflation is major determinant of tax revenue. Every 1\% increase in inflation determines $0.63 \%$ reduction in tax collection. During period of inflation people do not pay taxes, they have the opinion either they run their family or pay taxes. Usually, they find out the ways to evade from taxes. The political instability that was measured by using PI Index indicates inverse and significant relationship with tax collection. The results state that during democracy tax revenue decreases while in the period of dictatorship tax collection increases. The reason behind this is that during democracy, chances of non-transparent taxation system increase due to the occurrence of political instability and corrupt activities in the tax collection system. Corruption was determined by using corruption index which ranges from 0 to 6 . More corruption is indicated by 0 while 6 represent less corruption. The results suggested that every $1 \%$ increase in corruption decreases tax revenue by $0.67 \%$.Usually, people find out shortcut ways to evade from taxes when taxes are imposed, therefore, the corrupt activities of tax administrators caused reduction in tax collection.

Short run dynamics of the model revealed that ECM value is -0.27 which shows the convergence towards equilibrium in four years with $27 \%$. Per annum, R-square $\left(\mathrm{R}^{2}\right)$ showed $97 \%$ variation in dependent variable existed by independent variables. Adjusted- $\mathrm{R}^{2}$ was 0.95 showed $95 \%$ variation existed by significant variables. F-statistics showed goodness of fit of the model. DW statistics was 2.40 indicated the problem of autocorrelation does not exist in the model.

\subsubsection{Stability Test}

The stability test was used to check the stability of the model. [27] introduced two stability tests that are Cumulative Sum of Recursive Residuals (CUSUM) and Cumulative Sum of Square Recursive Residuals (CUSUMSQ) tests to check the stability of models. In present study, these tests were applied to check the stability of all models presented in the study. 
In figure $1 \&$ figure 2, the stability of the models was checked by using CUSUM and CUSUMSQ tests [27] and used critical straight lines as boundaries of tests. On vertical axis, the critical values are shown while horizontal axis represents year from 1981-2010. If CUSUM and CUSUMSQ cross the critical lines, the model considered unstable. In figure 1 \& figure 2 of stability test the zigzag lines lie between $5 \%$ critical bounds showing stability of the model.

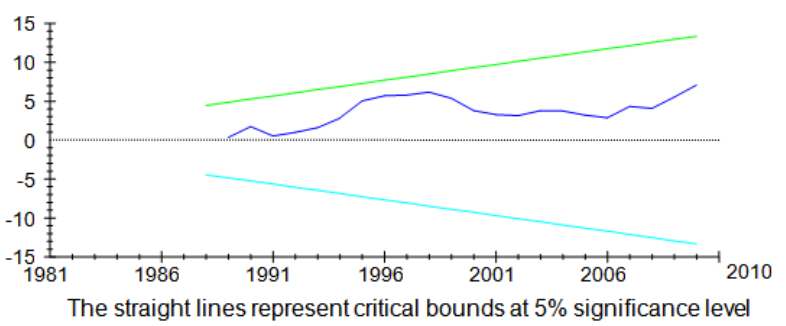

Figure 1. Cumulative Sum of Recursive Residuals (CUSUM)

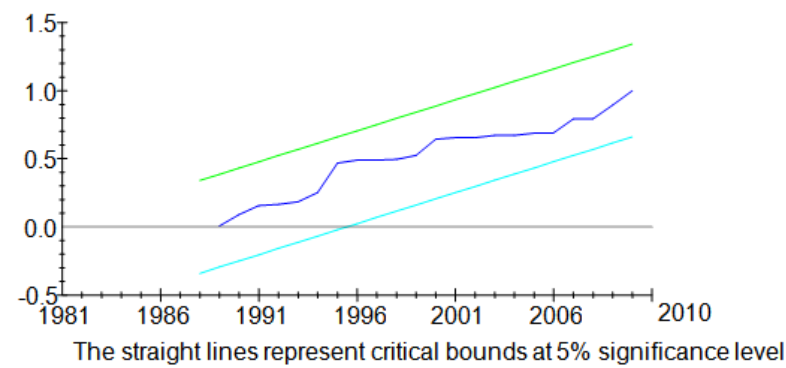

Figure 2. Cumulative Sum of Square Recursive Residuals (CUSUMSQ)

\subsection{Model 2: Indirect Tax to GDP Ratio}

The model below is developed to check how various factors affect tax collection id the tax levied is only in the form of indirect tax which is most prevalent in Pakistan like other developing country.

$$
\begin{aligned}
& \Delta \text { LOGIT / GDP } P_{t i}=\alpha+\sum_{i=1}^{k} \beta_{i} C I_{t-i}+\sum_{i=1}^{k} \chi_{i} P I_{t-i}+\sum_{i=1}^{k} \delta_{i} L_{\text {OOGCPI }}+ \\
& \sum_{i=1}^{k} \phi_{i} L_{t-i} \text { OGRPCI } I_{t-i}+\sum_{i=1}^{k} \lambda_{i} \text { LOGTO }_{t-i}+\sum_{i=1}^{k} \eta_{i} L O G I T / G D P_{t-i}+ \\
& \sum_{i=1}^{k} v_{i} \Delta C I_{t-i}+\sum_{i=1}^{k} \varpi_{i} \Delta P I_{t-i}+\sum_{i=1}^{k} \theta_{i} \Delta L O G C P I_{t-i}+ \\
& \sum_{i=1}^{k} \sigma_{i} \Delta L O G R P C I_{t-i}+\sum_{i=1}^{k} \omega_{i} \Delta L O G T O_{t-i}+\sum_{i=1}^{k} \zeta_{i} \Delta I T / G D P_{t-i}
\end{aligned}
$$

Model (2) explains how various factors such as corruption, political instability, real per capita income, trade openness and inflation affect indirect tax collection in Pakistan. Indirect tax revenue was measured by using indirect tax to GDP ratio.

Using ADF test for checking of stationarity, the results showed that corruption, political instability index, log of real per capita income and log of trade openness were stationary at first difference or I(1). While log of consumer price index and log indirect tax to GDP (logITX/GDP) were stationary at level. Probability

\begin{tabular}{|c|c|c|c|c|c|c|}
\hline \multirow{2}{*}{ Variables } & \multicolumn{3}{|c|}{ At level } & \multicolumn{3}{|c|}{ At $1^{\text {st }}$ difference } \\
\hline & Test Stat & Prob & Results & Test Stat & Prob & Results \\
\hline LOGITX/GDP & -1.96 & 0.59 & Non Stationary & $-4.30^{* *}$ & 0.01 & Stationary \\
\hline CI & -2.82 & 0.19 & Non Stationary & $-4.10^{* *}$ & 0.01 & Stationary \\
\hline PI & -1.53 & 0.79 & Non Stationary & $-5.04^{* * *}$ & 0.00 & Stationary \\
\hline LOGTO & -2.79 & 0.20 & Non Stationary & $-6.61^{* * *}$ & 0.00 & Stationary \\
\hline LOGRPCI & -1.96 & 0.59 & Non Stationary & $-5.72^{* * *}$ & 0.00 & Stationary \\
\hline LOGCPI & $-5.59^{* * *}$ & 0.00 & Stationary & -2.79 & 0.20 & Non Stationary \\
\hline
\end{tabular}
revealed that these variables were significant at $1 \%$ and $5 \%$ level of significance.

Table 5. Testing Stationarity of Variables using Augmented Dickey Fuller Test

Table 6. Bound Test Results

\begin{tabular}{|c|c|c|c|c|c|c|c|}
\hline \multirow{2}{*}{ F value } & \multirow{2}{*}{ Probability } & \multicolumn{3}{|c|}{ Critical value at 1\% } & \multicolumn{2}{c|}{ Critical value at 5\% } & \multicolumn{2}{c|}{ Critical value at $10 \%$} \\
\cline { 2 - 9 } & & $\mathrm{I}(0)$ & $\mathrm{I}(1)$ & $\mathrm{I}(0)$ & $\mathrm{I}(1)$ & $\mathrm{I}(0)$ & $\mathrm{I}(1)$ \\
\hline $5.96^{* *}$ & 0.00 & 3.03 & 4.06 & 4.47 & 4.57 & 4.40 & 5.72 \\
\hline
\end{tabular}

** shows $10 \%$ significance level applying bound test. The calculated value of F-statistics was checked against critical value of Pesaran table of unrestricted intercept and trend [26]. In table (6), the calculated F-value is 5.96 that is greater than upper bound

\begin{tabular}{|c|c|c|c|c|c|}
\hline \multirow{2}{*}{ Variables } & \multicolumn{2}{|c|}{ Long Run Dynamics } & \multirow{2}{*}{ Variables } & \multicolumn{2}{|c|}{ Short Run Dynamics } \\
\hline & Coefficient & $\mathrm{t}$ - value & & Coefficient & t- value \\
\hline LOGCPI & $-0.00 * * *$ & -5.19 & $\Delta$ LOGCPI & $0.00 * * *$ & 2.93 \\
\hline LOGTO & -0.92 & $\begin{array}{l}-1.58 \\
\end{array}$ & $\Delta$ LOGTO & -0.14 & -1.29 \\
\hline LOGRPCI & 0.00 & 1.70 & $\triangle$ LOGRPCI & -0.22 & -0.83 \\
\hline PI & $-0.17 * * *$ & -5.20 & $\Delta \mathrm{PI}$ & $-0.20 * *$ & -2.40 \\
\hline CI & $0.14^{* * *}$ & 4.39 & $\Delta \mathrm{CI}$ & $0.51^{* *}$ & 2.56 \\
\hline \multirow[t]{6}{*}{ CONSTANT } & 0.47 & 0.41 & $\Delta$ CONSTANT & 0.21 & 0.40 \\
\hline & & & ECM & $-0.45 * * *$ & -4.78 \\
\hline & & & R2 & 0.98 & \\
\hline & & & Adjusted R2 & 0.95 & \\
\hline & & & F Stat & 40.01 & \\
\hline & & & DW & 2.30 & \\
\hline
\end{tabular}
at $1 \%$ level of significance which indicates existence of long run relationship among variables.

Table 7. Long run and short run dynamics of Direct Tax to GDP Ratio 
It was obvious from the finding that inflation was negatively and significantly related with indirect taxes in Pakistan. When taxes are indirectly imposed on commodities people do not purchase commodities, which will eventually create inflation in the economy. Due to reduction in the purchasing power, tax collection automatically decreases. The political instability results showed tax revenue decreases with the increase in political instability index. T-value was 5.20 which support the significant impact of variable on indirect taxes. During democracy, evasion from corrupt activities are raised and chances of increasing tax collection decreases. Corruption index was positively and significantly related with indirect taxes. The positive value of corruption index indicated corruption index increasing which ultimately decreases corruption. During dictatorship, tax administrators usually evade from corrupt activities so it enhances the chances of increasing tax collection.

Short run results showed ECM value is -0.45 which leads to the convergence towards equilibrium in three years and single quarter with $45 \%$. Per annum. R-square $\left(\mathrm{R}^{2}\right)$ indicated 98\% variation in dependent variable existed by independent variables. Adjusted- $\mathrm{R}^{2}$ was 0.95 showed $95 \%$ variation done by significant variables. F-statistics showed goodness of fit of the model. DW statistics was 2.30 indicated non existence of autocorrelation.

\subsubsection{Stability Test}

The stability test is used to check the stability of the model. In present study, the stability of the model was checked by using Cumulative Sum of Recursive Residuals (CUSUM) and Cumulative Sum of Square Recursive Residuals (CUSUMSQ) tests.

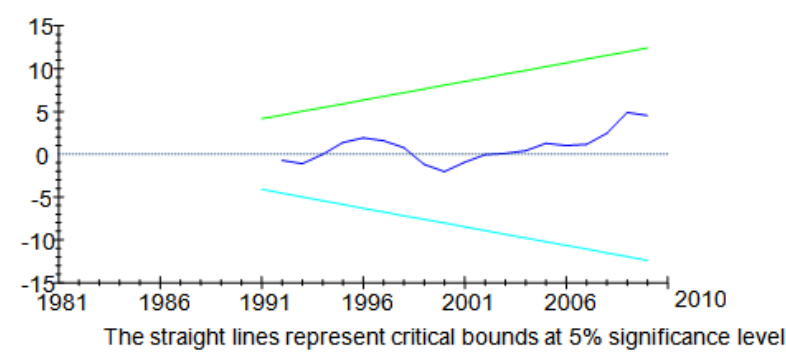

Figure 3. Cumulative Sum of Recursive Residuals (CUSUM)

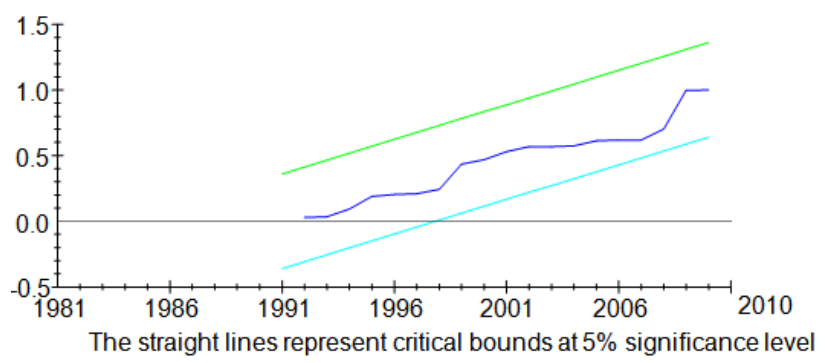

Figure 4. Cumulative Sum of Squares of Recursive Residuals (CUSUMSQ)

In figure 3 \& figure 4 , the stability of the model was checked by using CUSUM and CUSUMSQ tests. The model is considered unstable in case of CUSUM and CUSUMSQ cross the critical straight lines. In above figures, the zigzag lines lie between 5\% critical bounds showing model is stable.

\subsection{Model 3: Direct plus indirect tax to GDP ratio}

Now the model described below is developed to check how these factors have effect on direct tax collection system,

$$
\begin{aligned}
& \Delta T A X / G D P_{t i}=\alpha+\sum_{i=1}^{k} \beta_{i} C I_{t-i}+\sum_{i=1}^{k} \chi_{i} P I_{t-i}+\sum_{i=1}^{k} \delta_{i} T O_{t-i}+ \\
& \sum_{i=1}^{k} \phi_{i} R P C I_{t-i}+\sum_{i=1}^{k} \lambda_{i} L O G C P I_{t-i}+\sum_{i=1}^{k} \eta_{i} T A X / G D P_{t-i}+ \\
& +\sum_{i=1}^{k} v_{i} \Delta C O R R_{t-i}+\sum_{i=1}^{k} \varpi_{i} \Delta P I_{t-i}+\sum_{i=1}^{k} \theta_{i} \Delta T O_{t-i}+ \\
& \sum_{i=1}^{k} \sigma_{i} \Delta R P C I_{t-i}+\sum_{i=1}^{k} \omega_{i} \Delta L O G C P I_{t-i}+\sum_{i=1}^{k} \zeta_{i} \Delta T A X / G D P_{t-i}
\end{aligned}
$$

Following [15] the present study extends the model by introducing an additional variable political instability with more data range from 1980-2010 to study effects of various factors such as corruption, political instability, real

\begin{tabular}{|c|c|c|c|c|c|c|}
\hline \multirow{2}{*}{ Variables } & \multicolumn{3}{|c|}{ At level } & \multicolumn{3}{|c|}{ At $1^{\text {st }}$ difference } \\
\hline & Test Stat & Prob & Result & Test Stat & Prob & Result \\
\hline Tax/GDP & -2.20 & 0.46 & Non Stationary & $-5.96^{* * *}$ & 0.000 & Stationary \\
\hline $\mathrm{CI}$ & -2.82 & 0.19 & Non Stationary & $-4.10^{* *}$ & 0.015 & Stationary \\
\hline PI & -1.53 & 0.79 & Non Stationary & $-5.04^{* * *}$ & 0.001 & Stationary \\
\hline TO & -2.92 & 0.17 & Non Stationary & $-6.80^{* * *}$ & 0.000 & Stationary \\
\hline RPCI & -1.44 & 0.82 & Non Stationary & $-5.66^{* * *}$ & 0.000 & Stationary \\
\hline Log CPI & $-5.59^{* * *}$ & 0.00 & Stationary & -2.79 & 0.208 & Non Stationary \\
\hline
\end{tabular}
per capita income, trade openness and inflation on total (direct plus indirect) tax to GDP ratio in Pakistan.

Table 8. Testing Stationarity of Variables using Augmented Dickey Fuller Test

**, ** shows significance level at $1 \%$ and $5 \%$ respectively
Table (8) showed that tax/GDP (tax/GDP), corruption index, political instability index, real per capita income

and trade openness were stationary at $1^{\text {st }}$ difference while $\log$ CPI was stationary at level.

Table 9. Bound Test Result

\begin{tabular}{|c|c|c|c|c|c|c|c|}
\hline \multirow{2}{*}{ F-value } & \multirow{2}{*}{ Probability } & \multicolumn{2}{|c|}{ Critical value (At 1\%) } & \multicolumn{2}{c|}{ Critical value (At 5\%) } & \multicolumn{3}{c|}{ Critical value (At 10\%) } \\
\cline { 2 - 8 } & & $\mathrm{I}(0)$ & $\mathrm{I}(1)$ & $\mathrm{I}(0)$ & $\mathrm{I}(1)$ & $\mathrm{I}(0)$ & $\mathrm{I}(1)$ \\
\hline $5.13^{* * *}$ & 0.00 & 3.60 & 4.90 & 2.87 & 4.00 & 2.53 & 3.59 \\
\hline
\end{tabular}


The long run relationship of variables was estimated by applying bound test. The calculated value of $\mathrm{F}$ statistics was checked against critical value of Pesaran table of unrestricted intercept and trend [26]. As calculated F value is 5.13 which is greater than upper bound at $1 \%$ level of significance showing existence of long run relationship among variables.

Table 10. Long run and short run dynamics of Direct Tax to GDP Ratio

\begin{tabular}{|c|c|c|c|c|c|}
\hline \multirow[b]{2}{*}{ Variables } & \multicolumn{2}{|c|}{ Long Run Dynamics } & \multirow[b]{2}{*}{ Variables } & \multicolumn{2}{|c|}{ Short Run Dynamics } \\
\hline & Coefficient & $\begin{array}{c}\mathrm{t}- \\
\text { value }\end{array}$ & & Coefficient & $\begin{array}{c}\mathrm{t}- \\
\text { value }\end{array}$ \\
\hline $\mathrm{CI}$ & $0.46^{* * *}$ & 2.93 & $\Delta$ LOGCPI & $37.95 * * *$ & 2.67 \\
\hline PI & $-0.05^{* * *}$ & -4.92 & $\Delta \mathrm{TO}$ & $0.14^{* * *}$ & 3.83 \\
\hline TO & $0.07^{* *}$ & 1.83 & $\triangle \mathrm{RPCI}$ & $-0.02 * *$ & -2.30 \\
\hline LOGCPI & 0.53 & 0.71 & $\Delta \mathrm{PI}$ & -0.00 & -0.13 \\
\hline RPCI & $-0.02^{* * *}$ & -5.28 & $\Delta \mathrm{CI}$ & $1.24 * *$ & 2.17 \\
\hline \multirow[t]{6}{*}{ Constant } & $10.85^{*}$ & 10.47 & $\Delta$ Constant & $29.10^{* * *}$ & 4.37 \\
\hline & & & ECM(-1) & $-2.68^{* * *}$ & -5.69 \\
\hline & & & R2 & 0.94 & \\
\hline & & & $\begin{array}{c}\text { Adjusted } \\
\text { R2 } \\
\end{array}$ & 0.83 & \\
\hline & & & F-statistics & $\begin{array}{l}10.09 \\
(.000)\end{array}$ & \\
\hline & & & DW & 2.33 & \\
\hline
\end{tabular}

The results showed tax revenue increases with the decrease in corruption. T-statistics showed the significance level of variable at $1 \%$. [17,18,27,28] also found negative and significant relationship between corruption and tax revenue. Political instability index showed an inverse but significant relationship with tax revenue. The coefficient value indicated tax revenue increases with the decrease in political instability. Fair tax collection depends upon stabilization of the economy. Pakistan has worsened political situation which ultimately affects tax revenue. That's why the coefficient sign was not surprising. Trade openness showed positive and significant relationship with tax revenue. The coefficient value was 0.07 which indicated that one unit increase in trade openness increases tax collection by 0.07 units. $[4,18,25]$ also found strong positive and significant relationship between trade openness and tax collection. Real per capita income showed negative and significant relationship with tax revenue. Usually it is expected that a rise in per capita income raises tax collection. But for different categories of taxes, impact of per capita income on taxes also varies. In Pakistan, imposition of direct taxes is worse, evasion from taxes is on top and the political authorities in Pakistan are not in favor of the imposition of taxes on income of individual. All such are responsible for negative relationship between per capita income and tax revenue in Pakistan. [4] also found negative and significant relationship between per capita income and tax revenue. Consumer price index (CPI) was used as a proxy of inflation. The results showed inflation has positive but insignificant relationship with tax revenue. [4] also found a positive but insignificant relationship between inflation and tax collection.

Short run results showed ECM value is -.2.68 which shows the convergence towards equilibrium in six months. $\mathrm{R}$-square $\left(\mathrm{R}^{2}\right)$ indicated 94\% variation in dependent variable existed by independent variables. Adjusted- $\mathrm{R}^{2}$ was 0.83 showed $83 \%$ variation done by significant variables. Fstatistics showed goodness of fit of the model. DW statistics was 2.33 indicated non existence of autocorrelation.

\subsubsection{Stability Test}

The stability test is used to check the stability of the model. In present study, the stability of the model was checked by using Cumulative Sum of Recursive Residuals (CUSUM) and Cumulative Sum of Square Recursive Residuals (CUSUMSQ) tests.

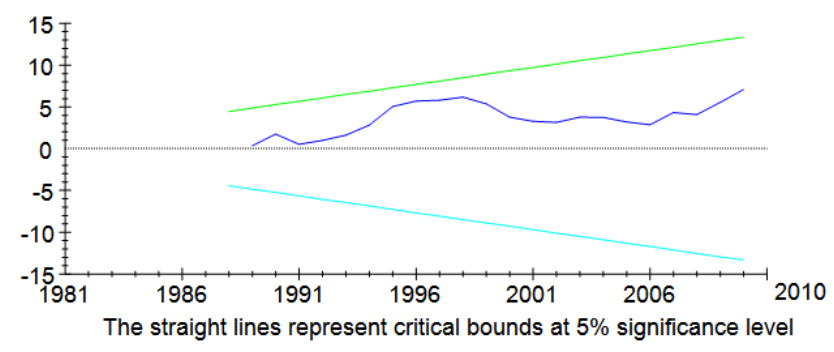

Figure 5. Cumulative Sum of Recursive Residuals (CUSUM)

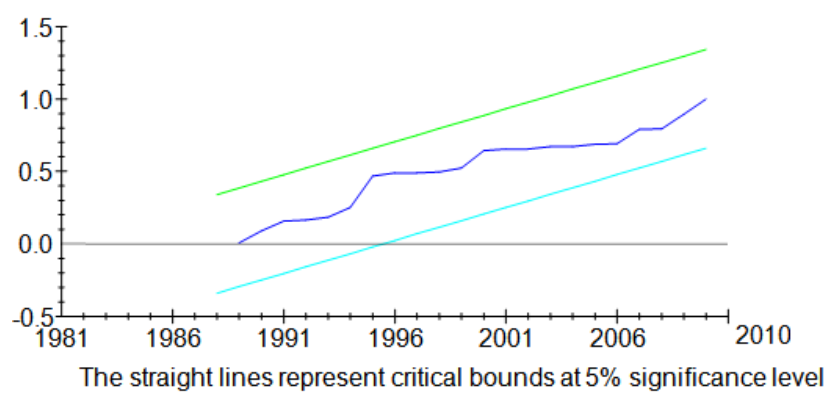

Figure 6. Cumulative Sum of Squares of Recursive Residuals (CUSUMSQ)

In above figures the stability of the model was checked by using CUSUM and CUSUMSQ tests. In above figures, the zigzag lines lie between $5 \%$ critical bounds showing model is stable.

\section{Conclusion and Policy Recommendations}

The effect of various factors that affect tax revenue in Pakistan has been analyzed in present study. Corruption, political instability, trade openness, real per capita income and inflation were considered as main determinants of tax collection. Tax to GDP ratio was used as an indicator of tax revenue. Empirical results revealed that taxes whether they are direct or indirect are more affected by corruption, political instability and inflation. An open economy put inverse impact on direct or indirect taxes. Increasing real per capita income also raises tax revenue. The results show corruption is major hurdle in raising tax revenue for both direct taxes and indirect taxes. Government should introduce more sophisticated online records and computerize all records through massive e-government campaign in all ministries and departments. The Govt should focus on creating awareness among people that paying tax is their moral and social obligation and it can be strengthen by improving the transparent collection and utilization of tax collected by improving societal welfare. Moreover, the inspection teams which are responsible for survey in taxation department should be counterchecked with online data obtained through different agencies to establish transparency. Increasing tax revenue can be obtained with elimination of restriction on trade and 
increasing more facilities in Export Promotion Bureau (EPB) and Trade Development Authority (TDA).

\section{References}

[1] Lutfunnahar, B. 2007. A Panel Study on Tax Effort and Tax Buoyancy with Special Reference to Bangladesh. Working Paper 715: Policy Analysis Unit (PAU) Research Department Bangladesh Bank

[2] Chaudhry, I., S. and Munir, F. 2010. Determinants of Low Tax Revenue in Pakistan. Pakistan Journal of Social Sciences (PJSS), 30 (2). 439-452.

[3] Nye, J. S. 1967. Corruption and Political Development: A CostBenefit Analysis', American Political Science Review, 61 (2). 417427.

[4] Glynn, P., Kobrin, S.J., and Naim.M. 1997. The Globalization of Corruption in Corruption and the Global Economy. Institute for International Economics, 7-27.

[5] Awan, A and Bakhsh, M. K. 2004. Anti-Corruption: Strategies in Pakistan Lahore: Book Biz.

[6] Chene, M. 2008. Overview of corruption in Pakistan. Retrieved May 17, 2010

[7] Transparency International 2011. Corruption Perception Index, Transparency International. Retrieved 1 December 2011.

[8] Tanzi, V. and Davoodi, H. 2000. Corruption, Public Investment and Growth. IMF working paper, 97/139. Washington, IMF.

[9] Richupan, S. 1984. Income Tax evasion: a review of the measurement of techniques and some estimates for the developing countries. Department of Memorandum No. DM/84/46. Washington, DC. The International Monetary Fund.

[10] Alm, J.,Bahl, R.W., and Murrey, M.N. 1991. Tax Base Erosion in Developing Countries. Economic Development and Cultural change, 39 (4). 849-872.

[11] Bird, R. M 1990. Expenditure, Administration and Tax Reform in Developing Countries. Bulletin for International Tax Documentation, 44. 263-267.

[12] Bird, R. M. 1992. Tax Policy and Economic development. Baltimore and London: The johns Hopkins University Press.

[13] Krugman, P.R., Alm, J., Collins, S.M., and Remolina, E. 1992. Transforming the Philippine Economy, Quezon City: APO Production Unit, Inc.
[14] Tanzi, V. 1998. Corruption around the world, causes and Consequences, Scope and Curse. Working Paper No. 98/63, IMF Fiscal Affairs Department, Washington DC, International Monetary Fund

[15] Ajaz, T., and Ahmad, E. 2010. The Effects of Corruption and Governance on tax Revenues. The Pakistan Development Review, 49 (4). 405-417.

[16] Gupta, A., S. 2007. Determinants of Tax Revenue Efforts in Developing Countries" IMF Working Paper No. 07/184 Washington, DC: The International Monetary Fund

[17] Tanzi, V. and Dvoodi, H. 1997. Inflation, Lags in Collection, and the Real Value of Tax Revenue Staff Papers International Monetary Fund, 24(1). 154-167.

[18] Imam, P., A. and Jacobs, D., F. 2007. Effect of Corruption on Tax Revenues in the Middle East. IMF Working Paper No. 07/270. IMF Institute and Fiscal Affairs Department

[19] Chelliah, R., J. 1971. Trends in Taxation in Developing Countries. International Monetary Fund, 18. 254-331.

[20] Government of Pakistan. 2012. Government of Pakistan, Federal Bureau of Revenue Pakistan.

[21] Patoli, A. Q., Zarif, T. and Syed, N., A. 2012. Impact of Inflation on Taxes in Pakistan: An empirical study of 2000-2010 period. Journal of Management and Social Sciences, 8 (2). 31-41.

[22] Aghevli, B., and Khan, M. 1978. Government Deficits and the Inflationary Process in Developing Countries. IMF Staff Papers 25. 383-415.

[23] Mahdavi, S. 2008. The Level and Composition of Tax Revenue in Developing Countries: Evidence from unbalanced panel data. International review of Economics and Finance, 17. 607-617.

[24] Aghevli, B., and Khan, M. 1978. Government Deficits and the Inflationary Process in Developing Countries. IMF Staff Papers 25, 383-415.

[25] Hwang, J. 2002. A Note on the Relationship between Corruption and Government Revenue, Journal of Economic Development, 27 (2). 161-177.

[26] Pesaran, M.H., Shin, Y. and Smith, R.J. 2010. Bound test approaches to analysis of long run relationship.

[27] Brown, R.L., Durbin, J., and Evans, J.M. (1975). Techniques for Testing the Constancy o Regression Relationships over Time. Journal of Royal Statistical Society, (2). 149-163.

[28] Potanler, S., K. Samimi, A., J. Roshan, A., R. 2010. Corruption and tax revenue: new evidence from some developing countries, Australian journal of basic and applied sciences, 4 (9). 4218-422. 